\title{
Jiribam, the Ornamental Fishes' Hot Spot Zone Of Manipur, India
}

\author{
Bijoya Khomdram, Bishal Dhar and Sankar Kumar Ghosh* \\ Department of Biotechnology, Assam University, Silchar-788011, Assam, India
}

\begin{abstract}
An investigation on the ornamental fish species availability was carried out in the Jiribam sub division, Imphal east district, Manipur, India. All the possible areas were surveyed and many experts were interacted. Out of the total 139 ornamental fishes found in the state of Manipur, 61 were recorded from Jiribam alone which comprise $44 \%$. Therefore, we can categorize Jiribam as one of the hot spots of ornamental fishes in Manipur. The total 61 species belonged to 22 families and 7 orders. 42 species were recorded as threatened species and 3 species are endemic.
\end{abstract}

Keywords: Jiribam, ornamental fish, hot-spot, endemic, threatened

\section{Introduction}

Due to the diversity of topographic and climatic features of NE India, this region is rich in endemic fish. Most of the small food fish which are treated as unwanted for conventional farming have good potency as ornamental fishes and are popularly known as Aquarium fishes. These species are attracting hobbyists both locally and globally.

North East India is considered as one of the hot spots of freshwater fish biodiversity in the world (Kottelat and Whitten, 1996). It is a well-recognized fact that there has been drastic reduction in abundance of the fresh water fishes in this region due to destruction of the habitat, overexploitation and other anthropogenic effects. Review of literature indicates that only limited information is available on fish germplasm resources of north east India with special reference to its potential as cultivable, sport and ornamental fishes. There has been a wide variation in the number of fishes reported from this region ranging from 172 (Ghosh and Lipton, 1982) to 267 (Sen, 2000). Also detailed drainage wise distribution, seasonal abundance, endemism and preferred microhabitats have not been critically examined.

The up to date inventory of the fish species of North East India showed 250 potential ornamental fish species. Out of this, the highest no. recorded from Assam (187), followed by Arunachal Pradesh (165), Meghalaya (159), Manipur (139), Tripura(103), Nagaland(71), Mizoram(46), and Sikkim(29). Conservation status of native ornamental fishes have shown that out of $250 \mathrm{sp}$., 10 are critically endangered, 28 are endangered, 49 are vulnerable, 45 are lower risk near threatened, 8 are lower risk least concern, 3 are data deficient and 107 are not evaluated (Ponniah, A. G. et al., 2006). NE harbors diversified native ornamental fish species. These include both classified and non-classified types of aquarium fishes (Mahapatra et al., 2004). Small fishes like Botia derio, Danio dangila, Puntius shalynius etc. are classified types on the other hand larger food fishes like Labeo gonius, Rita rita etc. are termed as non classified ones. There are two major river basins within the state of Manipur, viz. the Barak River Basin and the Manipur River Basin. After the world famous Shiroi Lily and the Sangai, matter has now come to light that Manipur is also home to a number of fish species which are highly prized for their ornamental values in Europe and the United States.

\section{Diversity of fish fauna in Jiribam, Manipur}

The north east region shares its fish fauna predominantly with that of the Indo Gangetic fauna and to a little extent with the Burmese and South China fish fauna (Yadav and Chandra, 1994). Exploring the literature shows that 172 fish species with reference to their economic importance were recorded by Ghosh and Lipton (1982) while Sen (1985) and Mahanta et al. (1998) recorded altogether 187 fish species from Assam and the neighboring north eastern states of India. Compilation of Yadav and Chandra (1994) listed a total of 129 species. Sinha (1996) in his comprehensive review gave a list of 230 species of fishes as available from north eastern region. Sen (2000) has indicated that more number of species (267) has been reported from north east India. The various reports show a wide variation in the total number of fishes reported. Since Manipur is located in the extreme east zone of India therefore there is a greater chance in the available fish fauna being influenced by Burmese fish fauna. According to recent reports, a total of 139 ornamental fishes are found in Manipur. Jiribam is a small sub division in the westernmost part of Manipur where it borders with the state of Assam. It is drained by a single river, Jiri River and many small canals. The Jiri River joins the Barak River in Tipaimukh and hence becomes the main reason of harboring a large number and variety of fishes. The literature reveals that no efforts have been made to explore the rich ichthyodiversity of this region and also no work have been done to 
assess the rich fish resources available in this region with respect to commercial utilization. With the growing demand for consumption and aquarium, it is necessary to evaluate potential species on the basis of different criteria.

In the present paper, an attempt has been made to prioritize among the fishes of this region the potential ornamental fishes along with their endemic status and status of threat on the basis of available literature as well as enquiry and interaction with the local fishery experts. Potential aquarium fishes have been identified based on actual present demand, bright coloration, uncommon look and uniqueness and following the records as mentioned in the literature. Recent estimates suggested that worldwide $20 \%$ of all freshwater fish species are extinct, endangered or vulnerable (Maclean and Jones, 1995). As a result fish stocks particularly those dwelling in inland open water areas, have gradually become endangered.

Extensive field survey conducted from September 2009 to December 2010 in Jiribam sub division of Manipur revealed the occurrence of bewildering diversity of ornamental fishes. Study about the species availability helps to know the present status of species variety and their relative abundance in the respective water bodies.

\section{Study area}

\section{Materials And Methods}

The survey work was carried out in Jiribam sub division (Imphal east district) of Manipur, India. Data were collected from all the major fish landing centers and interaction with the fishermen and local people.

\section{Data collection and analysis}

In order to collect data field visit was made every month and sometimes daily during the study period according to information and preference in the respective areas. In addition relevant information was also collected from various sources. The data were assembled through field survey using appropriate questionnaire. The questionnaire form was filled in by interviewing the fishermen directly from the field and local fish experts and also the local people. All the collected data were analyzed and the species observed were grouped in different categories.

\section{Species composition}

\section{Results And Discussion}

A total of 61 species were found from the surveyed area out of the total 139 species of ornamental fishes found in the state of Manipur. All the species were Freshwater fishes. They were belonged to 22 families and 7 orders. They are serially depicted in the tables 1, 2 and 3. Out of the 61 species recorded 21 species belonged to the family, Cyprinidae, only $1 \mathrm{sp}$. belonged to Anabantidae, 2 species belonged to Anguillidae, 1 species belonged to Badidae, 2 species from Balitoridae, 3 species from Ambassidae, 3 species from Channidae, 1 species from Clariidae, 3 species from Osphronemidae, 1 species from Erethistidae, 1 species from Schilbeidae, 3 species from Sisoridae, 4 species from Cobtidae, 5 species from Bagiridae, 1 species from Nandidae, 2 species from Notopteridae, 1 species from Mastacembelidae, 1 species from Chachidae , 1 species from Synbranchidae and 2 species from siluridae, 1 species from Heteropneustidae and 1 from the family Belonidae. Among the 7 orders of fishes found, the order Cypriniformes dominated others with a total number of 27 species then comes Siluriformes (15) and Perciformes ranked third with a total number of 12 species.

\section{Species variation in different season}

During the survey it was observed that not all species were available in all season. A total of 14 species were more available in winter season, 12 in summer and 35 fish species were available throughout the year. There were some species which were more available in summer but not in winter. And some species were available only in winter season. The species which have high ornamental value are mostly available during the months of October to December.

\section{Status of the fishes}

According to the IUCN (2008) Red List of all life forms, 16,928 species are threatened globally, and of these 1275 specie are fishes. There are 9 categories in the IUCN Red List namely, Ex- Extinct, EW- Extinct in the Wild, CR- Critically Endangered, EN- Endangered, VU- Vulnerable, LR/cd- Lower risk/ conservation dependent, NT- Near Threatened (includes LR/nt- Lower Risk/ near threatened), DD- Data deficient, LC-Least Concern (includes LC/lc- Lower Risk/ least concern). Species may move between categories for a variety of reasons, including genuine improvement or deterioration in status, new information being available about the species that was not known at the time of previous assessment, taxonomic changes, or mistakes being made in previous assessment (eg., incorrect information used previously, misapplication of the IUCN Red List criteria, etc,). Out of the 61 species of ornamental fishes recorded from Jiribam, 42 species are found to be in the list of 
threats according to the report of CAMP workshop on freshwater fishes of India organized by NBFGR, 1997 and also following the records in the recent NBFGR publication (Lakra, W. S. et al., 2010), after exercising all the related records and publications. These fishes are shown in Table 4 with their category of threat. And we observed 3 endemic fishes in jiribam namely, Devario acuticephala, Schistura manipurensis and Garra manipurensis. Except these 3 species, others are native.

In the present study, the percentage contribution of Cyprinids are found to be $33.3 \%$ being the dominant family. Some fishes are found to be surprisingly in the verge of extinction. The noted ornamental fish Chaca chaca is reported to be found in some restricted area of Jiribam but due to some reasons we are facing a great problem in getting this fish. The major reason behind the threatening status of this particular fish is the construction of Tipaimukh dam in the water body which is the sole and native home for this very species of ornamental fish. Bagarius bagarius is almost extinct in Jiribam nowadays, during the whole survey period it was recorded to catch only once in the month of December. During the last few years many exotic fishes are also introduced by the fishermen so that they could get a greater profit in their business without a second thought of affecting the local and indigenous fish diversity of the area. Freshwater fish are not only the most diverse group of vertebrates but they also represent and feature the greatest proportion of threatened species (Bruton, 1995; Leidy and Moyle, 1998; Duncan and Lockword, 2001). The principal threats to freshwater fish are the deterioration or destruction of habitats, both by pollution and intense modifications (like damming, channelization and so on.) and introduction of exotic species (Moyle,1986; Allan and Flecker, 1993). Though most of the fish resources of Manipur are already explored by Vishwanath and his team (Vishwanath and Sarojnalini, 1986, Vishwanath et al., 2007, Vishwanath and Dishma, 2012), the fish species of Jiribam region remain untouched. The present study will help future researchers and others for easy access of the ornamental fishes of this region and will be of great help to conservationist and aquarists.

\section{Acknowledgement:}

We would like to thank to the Department of Biotechnology (DBT), Government of India, for providing the infrastructural fund. The funder had no role in study design, data collection and analysis, decision to publish, or preparation of the manuscript. No additional external funding received for this study.

\section{References}

[1]. Allan, J.D. and Flecker, A.S. (1993). Biodiversity conservation in running waters. Bioscience. 43: 32-43.

[2]. Bruton, M.N. (1995). Have fish had their chips? The dilemma of threatened fishes. Environmental Biology of Fishes. 43: 1-27.

[3]. Duncan, J.R. and Lockwood, J.L. (2001). Extinction in a field of bullets: a search for causes in the decline of the world's freshwater fishes. Biological Conservation. 102: 97-105.

[4]. Ghosh, S.K. and Lipton, A.P. (1982). Ichthyofauna of the NEH Region with Special Reference to Their Economic Importance. ICAR Spl. Bulletin No.1, 119-126.

[5]. Kottelat, M. and Whitten, T. (1996). Freshwater Biodiversity in Asia with special reference to fish. World Bank Tech. Paper No. 343. The World Bank, Washington DC. 17-22.

[6]. Lakra, W.S., Sarkar, U.K., Gopalakrishnan, A. and Kathivelpandian, A. (2010). Threatened freshwater fishes of India. NBFGR publication. Lucknow.

[7]. Leidy, R.A. and Moyle, P.B. (1998). Conservation status of the world's freshwater fish fauna: an overview. Conservation Biology: For the Coming Decade, $2^{\text {nd }}$ edition. Fielder, P.L. Karieva, P.M. (eds). Chapman and Hall: New York. 187-227.

[8]. Maclean, R.H. and Jones, R.W. (1995). Aquatic Biodiversity Conservation: a review of current issues and efforts. Ottawa. ON. SIFR.

[9]. Mahapatra, B.K., Vinod, K. and Manda,1 B.K. (2004). Ornamental fish of North Eastern

[10]. India - Its distribution and conservation status. Environment Ecol. 22(3): 674-683.

[11]. Moyle, P.B. (1986). Fish introductions into North America: patterns and ecological impact. Ecology of Biological Invasions of North America and Hawaii. Springer -Verlag: Berlin. 27-43.

[12]. Ponniah, A.G. and Sarkar, U.K. (2006). Evaluation of North East Indian Fishes for their Potential as Cultivable, Sport and Ornamental Fishes along with their Conservation and Endemic Status. NBFGR, Lucknow.

[13]. Sen, N. (2000). Occurrence, distribution and status of diversified fish fauna of North East India. Occasional paper. Zoological survey of India.

[14]. Sen, T.K. (1985). The fish fauna of Assam and the neighbouring north eastern states of India. Occasional paper No. 64, Records of Zoological Survey of India. 1-216.

[15]. Sinha, M. (1994a). Threatened Coldwater Fishes of North Eastern India. Threatened Fishes of India. Natcon Publication, No. 4, UP. 173-176.

[16]. Vishwanath, W. and Dishma, M. (2012). Barilius profundus, a new cyprinid fish (Teleostei: Cyprinidae) from Koladyne basin, India. Journal of Threatened Taxa 4(2): 2363-2369.

[17]. Vishwanath, W, Lakra, W.S. and Sarkar, U.K. (2007). Fishes of North East India. National Bureau of Fish Genetic Resources, Lucknow, UP, India, 264.

[18]. Viswanath, W. and Sarojnalini, Ch. (1986). A new cyprinid fish, Garra manipurensis, from Manipur, India. Japanese Journal of Ichthyology. 35(2): 124-126p.

[19]. Yadava, Y.S. and Chandra, R. (1994). Some threatened carps and catfishes of Brahmaputra river system. Threatened Fishes of India. Natcon Publication No.4. UP. 45-55. 
Table 1:- List of the ornamental fishes being collected from Jiribam. (A-abundant,LA- less abundant, MAmoderately abundant, R-rare, VR-very rare)

\begin{tabular}{|c|c|c|c|c|}
\hline $\begin{array}{l}\text { Sl } \\
\text { no }\end{array}$ & Local name & Scientific name & Ornamental value & Abundance \\
\hline 1 & Muka nga & Amblypharyngodon mola & Medium & $\mathrm{A}$ \\
\hline 2 & Ngawa & Barillius ngawa & High & $\mathrm{R}$ \\
\hline 3 & Ngawa phuri thungbi & Barillius bendelisis & High & $\mathrm{R}$ \\
\hline 4 & Muka nga macha & Devario acuticephala & High & $\mathrm{A}$ \\
\hline 5 & Ngasang & Esomus dbnricus & High & $\mathrm{A}$ \\
\hline 6 & Ngasang macha & Rasbora rasbora & High & MA \\
\hline 7 & Ngathi & Labeo calbasu & Medium & $\mathrm{R}$ \\
\hline 8 & Khabak & Labeo gonius & Medium & MA \\
\hline 9 & Phabou & Puntius manipurensis & High & $\mathrm{R}$ \\
\hline 10 & Phabou & Puntius punctata & Medium & MA \\
\hline 11 & Phabou & Puntius sarana & High & MA \\
\hline 12 & Phabou & Puntius conchonius & Medium & MA \\
\hline 13 & Phabou & Puntius vittatus & High & MA \\
\hline 14 & Mirga & Cirhinus mrigala & Medium & A \\
\hline 15 & Ngara & Tor tor & High & $\mathrm{VR}$ \\
\hline 16 & Rou & Labeo rohita & Low & $\mathrm{A}$ \\
\hline 17 & Ukabi & Anabus testudineus & Medium & MA \\
\hline 18 & Ngaril & Anguilla bengalensis & High & $\mathrm{R}$ \\
\hline 19 & Ngaril leisna & Anguilla bengalensis Gray & High & VR \\
\hline 20 & Napet nga & Badis badis & High & MA \\
\hline 21 & Ngatup & Schistura sp. & Medium & $\mathrm{R}$ \\
\hline 22 & Ngatup & Schistura manipurensis & High & VR \\
\hline 23 & Ngamhai akoiba & Chanda nama & High & MA \\
\hline 24 & Ngamhai asangba & Chanda nama & High & MA \\
\hline 25 & Ngamhai anganba & Chanda nama & High & MA \\
\hline 26 & Porom & Channa marulia & High & MA \\
\hline 27 & Ngamu & Channa punctata & Medium & $\mathrm{A}$ \\
\hline 28 & Meitei ngamu & Channa orientalis & High & MA \\
\hline 29 & Ngakra & Clarias batrachus & High & $\mathrm{A}$ \\
\hline 30 & Ngabemma & Colisa chuna & High & MA \\
\hline 31 & Ngabemma & Colisa fasciata & High & MA \\
\hline 32 & Ngabemma & Colisa lalia & High & MA \\
\hline 33 & Samu khongpak & Erithistes hara & High & VR \\
\hline 34 & Basa & Eutropichthys vacha & Medium & MA \\
\hline 35 & Leingoi chabi & Gogangra viridescens & High & $\mathrm{R}$ \\
\hline 36 & Hangoi nga & Sisor rabdophorus & High & VR \\
\hline 37 & Ngakijou angangba & Lepidocephalichthys anandalei & High & MA \\
\hline 38 & Ngakijou amuba & Lepidocephalichthys guntea & High & MA \\
\hline 39 & Ngakijou awaoba & Lepidocephalichthys berdmorei & Medium & MA \\
\hline 40 & Sarengkhoibi & Botia derio & High & MA \\
\hline 41 & Ngasep & Mystus tengara & Medium & A \\
\hline 42 & Ngasep & Mystus vittatus & Medium & MA \\
\hline 43 & Ngachou & Sperata singhala & Medium & $\mathrm{R}$ \\
\hline 44 & Ngarel & Bagarius bagarius & High & $\mathrm{VR}$ \\
\hline 45 & Litha & Rita rita & Medium & MA \\
\hline 46 & Kharaobi & Nandus nandus & High & MA \\
\hline 47 & Kandla & Notopterus notopterus & Medium & MA \\
\hline 48 & Ngapai & Notopterus chitala & High & MA \\
\hline 49 & Ngamoi & Mastacembalus armatus & High & MA \\
\hline 50 & Ngaprum & Monopterus cuchia & Medium & MA \\
\hline 51 & Ngaseksha & Ompok pabda & High & $\mathrm{R}$ \\
\hline 52 & Gajeb bakau & Chaca chaca & High & VR \\
\hline 53 & Nunga amuba & Garra manipurensis & High & VR \\
\hline 54 & Nunga awaoba & Schizothorax richardsoni & High & $\mathrm{R}$ \\
\hline 55 & Ngaching & Gagata sp. & High & $\mathrm{R}$ \\
\hline 56 & Nga cheklaobi & Xenentodon cancila & High & MA \\
\hline 57 & Bata & Labeo bata & Low & MA \\
\hline 58 & Mitlangbi & garra sp. & Medium & $\mathrm{R}$ \\
\hline 59 & Ngamu sengum & Garra gotyla & Medium & $\mathrm{A}$ \\
\hline 60 & Ngachik & Heteropneustes fossilis & Medium & MA \\
\hline 61 & Sareng & Wallago attu & Medium & MA \\
\hline
\end{tabular}


Table 2:- Families of the ornamental fishes found in Jiribam along with the number of species

\begin{tabular}{|c|c|c|}
\hline Sl no. & Family & No. of species \\
\hline 1 & Cyprinidae & 21 \\
\hline 2 & Anabantidae & 1 \\
\hline 3 & Anguillidae & 2 \\
\hline 4 & Badidae & 1 \\
\hline 5 & balitoridae & 2 \\
\hline 6 & Ambassidae & 3 \\
\hline 7 & Channidae & 3 \\
\hline 8 & Clariidae & 1 \\
\hline 9 & Osphronemidae & 3 \\
\hline 10 & Erethistidae & 1 \\
\hline 11 & Schilbeidae & 1 \\
\hline 12 & Sisoridae & 3 \\
\hline 13 & Cobtidae & 4 \\
\hline 14 & Bagaridae & 5 \\
\hline 15 & Nandidae & 1 \\
\hline 16 & Notopteridae & 2 \\
\hline 17 & Mastacembelidae & 1 \\
\hline 18 & Chachidae & 1 \\
\hline 19 & Synbranchidae & 1 \\
\hline 20 & Siluridae & 2 \\
\hline 21 & Heteropneustidae & 1 \\
\hline 22 & Belonidae & 1 \\
\hline
\end{tabular}

Table 3:- Orders of the ornamental fishes found in Jiribam along with the number of species

\begin{tabular}{|c|c|c|}
\hline Sl no. & Order & No. of species \\
\hline 1 & Cypriniformes & 27 \\
\hline 2 & Perciformes & 12 \\
\hline 3 & Anguilliformes & 2 \\
\hline 4 & Siluriformes & 15 \\
\hline 5 & Osteoglossiformes & 2 \\
\hline 6 & beloniformes & 1 \\
\hline 7 & Synbranchiformes & 2 \\
\hline
\end{tabular}

Table 4:- Threatened species being detected in Jiribam sub division of Manipur based on NBFGR (National Bureau of Fish genetic Resources) data and report of CAMP (Conservation Assessment and Management Plan) workshop organized by NBFGR ( EN- Endangered, VU- Vulnerable, CR-Critically Endangered, LRnt- Lower Risk near threatened, LRlc- Lower Risk least concern).

\begin{tabular}{|r|l|l|}
\hline \multicolumn{1}{|l|}{ Sl no. } & Species name & category \\
\hline 1 & Puntius manipurensis & EN \\
\hline 2 & Sisor rabdophorus & EN \\
\hline 3 & Tor tor & EN \\
\hline 4 & Badis badis & VU \\
\hline 5 & bagarius bagarius & VU \\
\hline 6 & Botia derio & VU \\
\hline 7 & Eutropiichthys vacha & VU \\
\hline 8 & garra gotyla & VU \\
\hline 9 & Heteropneustes fossilis & VU \\
\hline 10 & Ompok pabda & VU \\
\hline 11 & Puntius sarana & VU \\
\hline 12 & Puntius vittatus & VU \\
\hline
\end{tabular}




\begin{tabular}{|c|c|c|}
\hline 13 & Schizothorax richardsoni & VU \\
\hline 14 & Notopterus chitala & EN \\
\hline 15 & Amblypharyngodon mola & LRlc \\
\hline 16 & Anabus testudineus & VU \\
\hline 17 & Anguilla bengalensis Gray & $\mathrm{EN}$ \\
\hline 18 & Channa marulia & LRnt \\
\hline 19 & Channa orientalis & VU \\
\hline 20 & Channa punctata & LRnt \\
\hline 21 & Cirhinus mrigala & LRnt \\
\hline 22 & Clarias batrachus & VU \\
\hline 23 & Colisa fasciata & LRnt \\
\hline 24 & Esomus danricus & LRlc \\
\hline 25 & Garra manipurensis & $\mathrm{CR}$ \\
\hline 26 & Rita rita & LRnt \\
\hline 27 & Schistura manipurensis & VU \\
\hline 28 & Wallago attu & LRnt \\
\hline 29 & Xenentodon cancila & LRnt \\
\hline 30 & Labeo bata & LRnt \\
\hline 31 & Labeo calbasu & LRnt \\
\hline 32 & Labeo rohita & LRnt \\
\hline 33 & Lepidocephalus anandalei & LRnt \\
\hline 34 & Lepidocephalus berdmorei & EN \\
\hline 35 & Monopterus cuchia & LRnt \\
\hline 36 & Mystus vittatus & VU \\
\hline 37 & Nandus nandus & LRnt \\
\hline 38 & Gogangra viridescens & LRnt \\
\hline 39 & Notopterus notopterus & LRnt \\
\hline 40 & Puntius conchonius & $\mathrm{VU}$ \\
\hline 41 & Puntius vittatus & VU \\
\hline 42 & Barilius bendelisis & LRnt \\
\hline
\end{tabular}

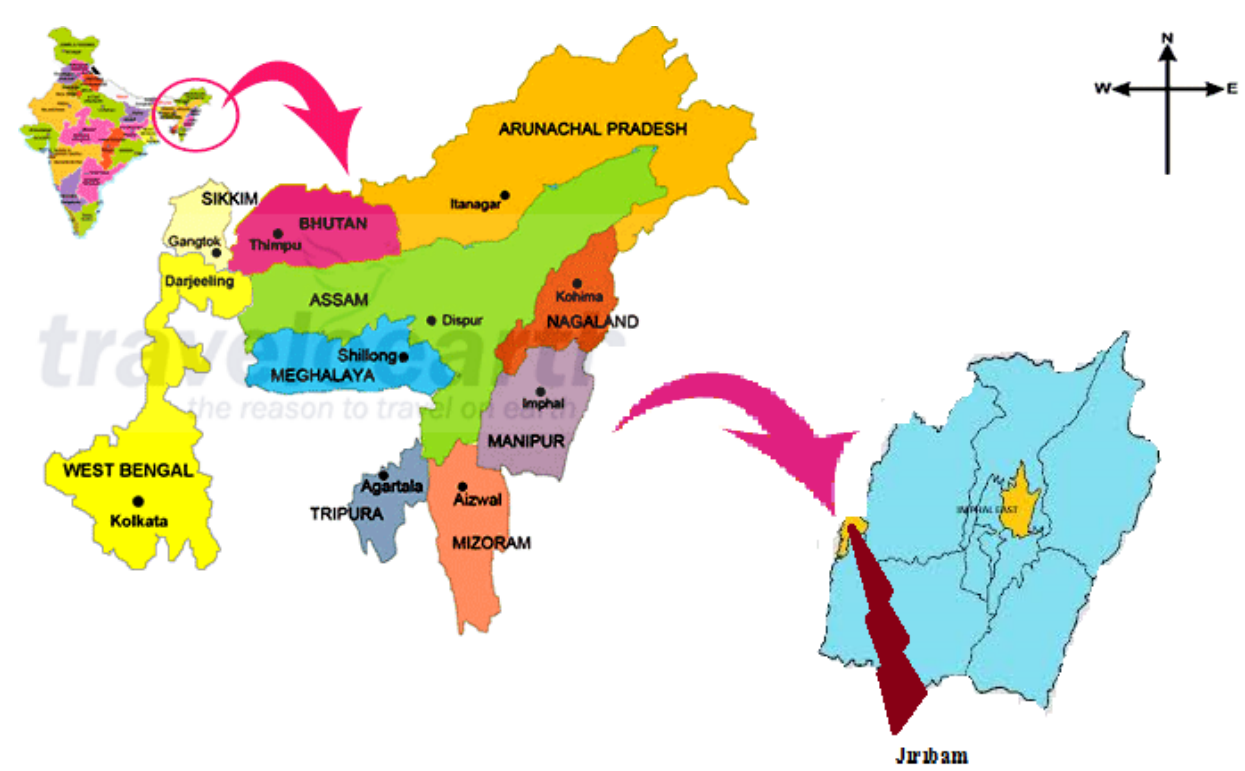

Figure 1. Map of India, Manipur, showing Jiribam, the study area (www.mapsofindia.com). 


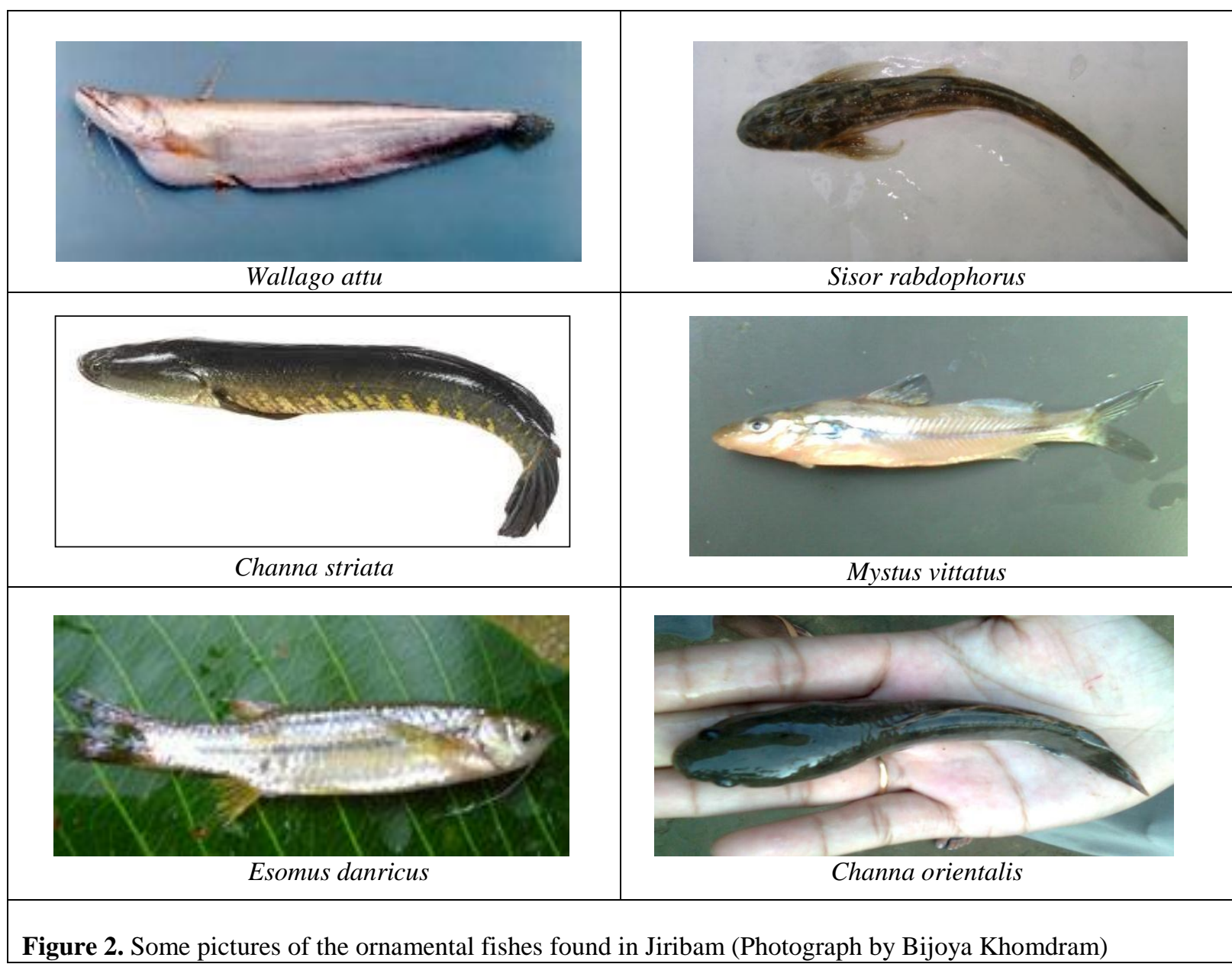

